\title{
Arendt Works Cited and Abbreviations Used
}

Eichmann in ferusalem (New York: Penguin, 1977), cited as Eichmann. The Human Condition (Chicago: University of Chicago Press, I958), cited as $\mathrm{HC}$.

The few as Pariab: Fewish Identity and Politics in the Modern Age, ed. Ron H. Feldman (New York: Grove Press, 1978), cited as Pariab.

The Life of the Mind (New York: Harcourt Brace Jovanovich, 1978), cited as Thinking.

On Revolution (New York: Penguin, I986), cited as OR.

The Origins of Totalitarianism (New York: Harcourt Brace Jovanovich, 1973), cited as The Origins.

Rabel Varnhagen: The Life of a fewish Woman, trans. Richard Winston and Clara Winston (New York: Harcourt Brace Jovanovich, 1974), cited as Rabel. 

Speaking through the Mask 
